\title{
ETHNOBOTANICAL STUDY OF INDIGENOUS KNOWLEDGE ON SOME WILD PLANTS IN PARSA DISTRICT, NEPAL
}

\author{
SHILA SINGH
}

\begin{abstract}
Tribhuvan University, Amrit Campus, Department of Botany, Kathmandu, Nepal singhshila@hotmail.com
\end{abstract}

\begin{abstract}
The present study was carried out to document ethnobotanical informations of some wild plants used by the Tharu community of Parsa district forest area of Nepal. This study was designed to gather primary folk knowledge on different plant based therapies used at four adjacent villages; Gadi, Madhuban mathwal, Sonbarsa and Shanker Sharaiya for various purposes through frequent field visits in the forest and adjoining villages, participatory observations, group discussion, interviews with tribal's and local knowledgeable people in the year 2013 from February to November. A total of 54 ethno-medicinal wild plant species belonging to 29 families and 44 genera were documented in this study. It can be concluded that Tharu community of the Parsa district possess valuable traditional knowledge on plant based therapies. Present documentation will provide novel information to protect traditional knowledge for the conservation and sustainable use of the rich biodiversity for future generations and serve to open the door for new pharmacological research.
\end{abstract}

Keywords: tribals, Tharu community, medicinal plants

\section{INTRODUCTION}

The term 'Ethnobotany' was coined by Harshberger in 1895 for plants. More than 6,000 species of vascular plants as well as many ethnic groups with different customs and language are found in Nepal (Rajbhandari, 2001). Scientists in Nepal are deeply distressed over the losses of Nepal's biodiversity and indigenous knowledge of the communities and have pledged themselves to find a way to arrest this destruction (Chaudhary,1998). Ethnobotany is considered to encompass all studies, which concern the mutual relationship between plants and traditional people (Cotton, 1996). Medicinal plants have been in use traditionally for times immemorial and have been serving the mankind. Recently updated database revealed a total of 1950 species of medicinal plants used in Nepal and out of which 1906 species are identified under vascular groups comprising 1614 native,192 introduced and/cultivated and 100 naturalized taxa (Ghimire, 2008). The plant and plant resources for medicinal use are collected by local people and herbal healer from various habitats such as forest, scrubland, grassland and cultivated fields and use them as crude drugs. It is known that the way of administration to cure disease using a particular plant widely differs among the indigenous people and also healers, jhakris and amchies (homeopathic/ayurvedic doctors) (Manandhar, 2002; Shrestha \& Dhillion, 2003). Ethnobotanical sudy based upon tharu community has been also done in other part of the country; Ethnobotanical study of Tharu tribes of Chitawan district (Dangol \& Gurung $1991,2002)$. Some knowledge about wonderful and effective medicines by the tribes acquired 
through experience is usually passed from generation to generation in the verbal form and is still used by common people in most part of the world. Although, ethnobotanical studies have been done in many different parts of the country but, comparatively very less work has been done in Parsa district. Particularly in four VDC's where this study was carried out, this type of work has been not done in past. The aim of the present work is to explore new ethnobotanical use of the wild plants in the local community as well as documentation of their use value

Tharu, the oldest ethnic group, prefers to live in forest areas with their primitive customs, culture and religions. They derive their general requirements of food, fuel and fodder from forest resources. Most importantly, they use plants or their parts for healing various diseases. Tribes have great role in conservation of forest areas as they consider the plants as the precious gift of 'God' for their significant position in their life for all living requirements. So, they do not want to cut the trees. Such approaches of tribes are not only supporting the forest conservation concept but also providing vital information on drug design and development for present population.

\section{Description of the study area}

Parsa District is located between $84^{\circ} 8^{\prime} \mathrm{E}$ and $85^{\circ} 27^{\prime} \mathrm{E}$ longitude and $27^{\circ}$ and $27^{\circ} 26^{\prime} \mathrm{N}$ latitude. The altitude of district varies between 122 to $925 \mathrm{~m}$ from sea level (fig.1). Three types of forests are found in this district; Sal forest, mixed hard wood forest and Khair Sisoo forest. Sal forest is dominated by Shorea robusta whereas, mixed hard wood forest is dominated by Terminalia bellirica, Terminalia tomentosa, Lagerstromia parviflora, Adina cardifolia, Toona ciliata and Shorea robusta and khair sisoo forest is dominated by Acacia catechu, Dalbergia latifolia and Bambax ceiba. The villages, where this study was carried out are situated side by side towards the southern side of the forest. In all villages Tharu community is in highest population.

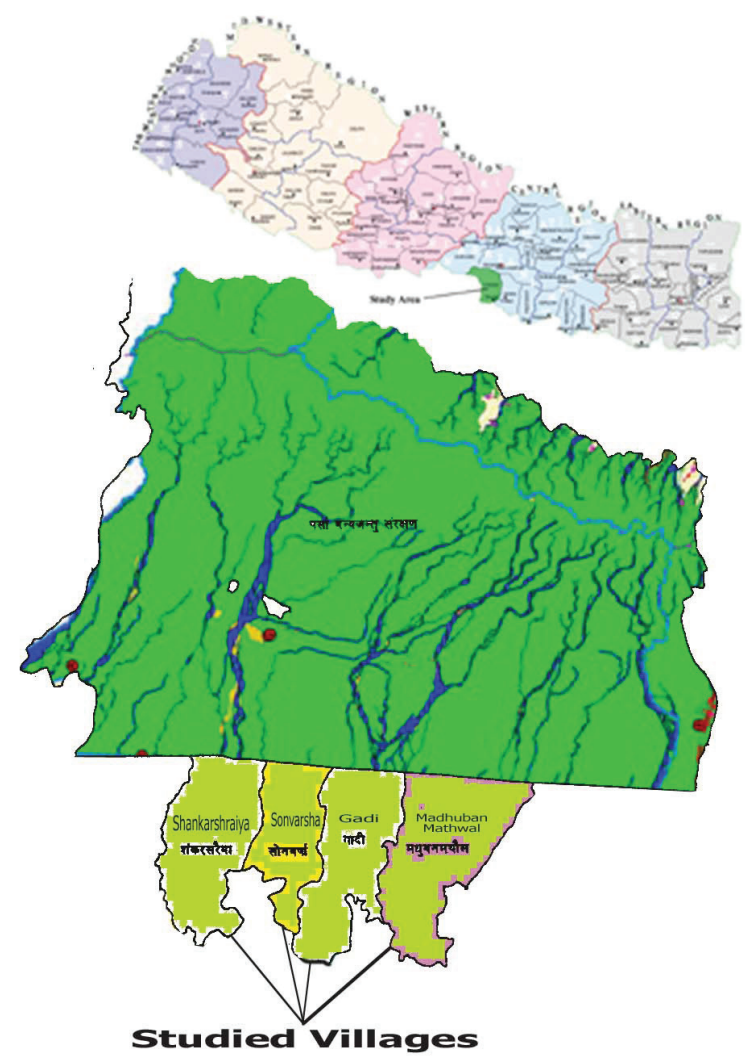

FIG.1. Map of the study area. 


\section{MATERIALS AND METHODS}

In order to document the utilization of the plants a total of four field surveys were carried out from March 2013 to November 2013 in the forest and adjoining four villages Madhuwan mathwal, Gadi, Shankar sharaiya and Sonbarsa. During field stay, plants were enumerated and several times interactions were done with the traditional healers, local knowledgeable old person and other informants like forest officers (Tharu) and few local people. The plants were collected for identification. Structured questionnaires, interviews and participatory observations were used to organize the information of the resource persons. Questionnaires include use of the plants for different purposes including medicinal use, parts of the plants used and detailed information about mode of preparation of medicines such as, decoction, powder, paste, juice and mixture of other plants used as ingredients. The plants were identified on the basis of related flora (HMG/ Nepal, 1970, 1984, 2001;Stainton,1988;Hooker, 1883) and verified by cross checking with the authentic voucher specimens present in the National Herbarium and Plant Laboratory, Godavari, Lalitpur, Nepal. Common names collected during interviews were compared with dictionary of Nepalese plant name (Shrestha,1998) to confirm common names of the plants. Plants were classified according to Cronquist classification. The use of various medicinal plants reported in this study was compared with previously published ethno botanical literature in Nepal and also adjoining areas of India.

\section{RESULTS AND DISCUSSION}

In this study, plants of ethnobotanical importance represent altogether 54 species distributed among 29 families and 44 genera. Poaceae was the most recorded plant family having 5 species followed by Caesalpiniaceae ( 4 species) and Zingeberaceae (4 species). Whereas plant families Asteraceae (3 species), Fabaceae (3 species), Mimosaceae (3 species), Combretaceae ( 3 species) and Lauraceae ( 3 species) were the third largest families in terms of number of species documented. Families Amaranthaceae ( 2 species) Acanthaceae ( 2 species) Myrtaceae (2 species) Rubiaceae (2 species) Euphorbiaceae (2 species) were fourth largest family. Whereas, faimily Agavaceae consists only one species. The inhabitants of the study area demonstrated an array of traditional knowledge.

The traditional knowledge of treating various kinds of diseases using different plant species

\section{Acacia arabica}

Medicinal value: Decoction of the bark is used as gargle for throat problems, in chronic dysentery and diarrhea. Young leaves are also used to cure gonorrhea. Bark along with salt are used as tooth-powder.

Other uses: The green leaves, pods and tender shoots are used as fodder for cattle.

\section{Acacia catechu}

Medicinal value: Powder prepared from the bark is given with honey to cure dysentery. Also used in case of hypertrophy of the tonsils. Decoction of the bark are used in case of skin diseases. Regular uses of bark powder by the barren females to conceive. 
Other uses: Katha, obtained from the plant is used as an ingredient of Pan. Heartwood is red and very hard.

\section{Achyranthes aspera}

Medicinal value: The paste of inflorescence is used for abortion. Root decoction obtained after boiling it in water is used to terminate pregnancy. Thin paste of root is used on lower abdomen for the induction of labor pain.

Other uses: Tender part of the stem is used as tooth brush by Hindu women in the festival Rishipanchami.

\section{Adhatoda vesica}

Medicinal value: Decoction of leaves, roots and the flowers are extensively used in case of cold, cough, bronchitis and asthma. Use of paste at the time of delivery by midwives.

\section{Adina cordifolia}

Medicinal value: Small buds are grinded with black pepper are sniffed into nose in severe headache.

Other uses: There is no heartwood. Seasoned wood takes a good polish and therefore, are used for the preparation of light toys. It is also used in construction of light furniture. Fruits are used for vegetable preparation.

\section{Aegle marmelos}

Medicinal value: Ripe fruit is used in dyspepsia and dysentery. The slice of pulps of unripe fruit is soaked in oil for a week. It is rubbed over the body before bathing to remove the peculiar burning sensation in the soles of the feet.

\section{Albizia lebbeck}

Medicinal value: Gum is used to cool the burning sensation on legs. Oil extracted from the seeds is used to cure leprosy. Powdered seeds are given to cure piles, diarrhea and gonorrhea.

\section{Aloe vera}

Medicinal value: Leaves are rubbed on scalp to promote growth of the hair. The pulp is used to treat sunburns, scars on the skin. It is used to cure several skin diseases such as eczema, dry skin.

\section{Amaranthus spinosus}

Medicinal value: The leaves of the plants are used in the treatment of internal bleeding, diarrhea, and excessive bleeding during menstruation.

Other uses: Young plant with green leaves, before flowering is boiled and with salt used as vegetable. It is also used as fodder. 


\section{Andrographis paniculata}

Medicinal value: The juice extracted from the leaves is mixed with the powder of cardamom, clove and cinnamon and dried in the sun. Small pellets are prepared from it. This is given to small children to cure irregular stools, loss of appetite.

\section{Andropogon muricatus}

Medicinal value: The paste of roots is used externally as a cooling against in case of high fever. Root powder is also given in case of thirst, inflammation, irritability of stomach. Paste of the root is rubbed on the skin to remove excessive heat or burning sensation of the body.

Other uses: Young leaves are used as fodder. During winter dry grass is used as bed for the cattle and for thatching purposes.

\section{Azadirachta indica}

Medicinal value: It cures skin diseases and purifies blood. Leaves are insecticidal and anthelmintic. Young twigs and fruits are anthelmintic and also good for cough, asthma, piles, tumors and urinary problems.

Other uses: The main stem after maturity is used for making furniture. Dried leaves are burnt to remove insects. Seeds are used for the extraction of oil. Oil has several applications.

\section{Bauhinia purporea}

Medicinal value: Decoction of bark is given in case of problems in the stomach. Dry flowers are used as laxative. Decoction of leaves along with the decoction of Ashwagandha is given in case of hormonal imbalance and also in liver complaints. Decoction of the bark is used as an astringent gargle.

Other uses: Bark is used for dying. Flowers are used as vegetables.

\section{Bixa orellana}

Medicinal value: Sap obtained from the fruit is used to treat diabetes.

Other uses: Seed is used by the tribals for painting the lips. It is used to paint body and color hairs and also to stain food products.

\section{Blumea lacera}

Medicinal value: Juice extracted from the leaves is used in infection by threadworm. Fresh root is held in mouth to cure or relieve dryness.

Other use: The leaves are cooked and eaten as sago. Juice of the fresh leaf is used as 'Kajol'.

\section{Boerhaavia diffusa}

Medicinal value The leaves are cooked and used to cure tumor, spleen enlargement, abdominal pains and joint pain. The extract of the seeds are used in scabies. Dried leaves are used to cure bronchial asthma.

Other uses: Tender parts are used as vegetable. It is also used as fodder. 


\section{Bombax ceiba}

Medicinal value: Dried young roots are powdered and given in case of impotence. Paste of the leaves is used externally to cure swelling of legs and arms. Gum mixed with water cure bleeding piles.

Other uses: Fiber is obtained from the fruits. The native use it for pillow, gadda etc. Poor people use the timber for construction of door. Leaves and young twigs are used as fodder for the cattle.

\section{Butea monosperma}

Medicinal value: Fresh juice obtained after incision of bark is used in case of ulcer. The flowers are used as a poultice in case of swellings. The shoot apex is used to prevent conception.

Other uses: Dried branches or twigs or even the main plant is used as fire wood. The flowers are used for worship. It is considered as sacred tree. Flowers yield yellow dye.

\section{Caesalpinia bonduc}

Medicinal value: Local people use leaf decoction in malaria along with the black pepper. Root decoction is used in hernia, sexual weakness and chicken pox.

Other uses: Seeds are used for making bracelets, necklaces. Oil extracted from the seeds is used in cosmetics to keep the skin soft.

\section{Cannabis sativa}

Medicinal value: The extract of the leaf is used to cure different kinds of tumors and mammary tumors. It is also used to treat bronchitis, burns, diarrhea, dysentery, epilepsy, gonorrhea, insomnia, jaundice, malaria, migraine, and whooping cough.

Other use: Leaves are used as narcotic agent.

\section{Careya arborea}

Medicinal value: Flowers are used as a tonic for the women after child birth. The experienced mid wives use the infusion of flower to heal ruptures caused after child birth.

Other uses: Ripe fruits are eaten by the local people. Some of the people use the dry bark as dye. The wood is used in the preparation of the agricultural implements.

\section{Cassia alata}

Medicinal value: Leaves are used in skin diseases particularly in ring worm. Root is dried and powdered with Terminalia chebula in equal ratio and this mixture is also used to cure ring worm. The decoction of leaves is used to treat high blood pressure. It is also used to cure venereal diseases such as syphilis and gonorrhea.

\section{Cassia fistula}

Medicinal value: The leaves extract is used as antibacterial and antifungal agent. The sweet blackish pulp of the seed is used as a mild laxative. The root decoction has great curative effects against common cold. Leaf juice is used in curing fungal infections of the skin. 


\section{Centipeda minima}

Medicinal value: Leaves are used to cure skin diseases such as itching, dry skin due to psoriasis. When the aroma of the squeezed flower heads is inhaled, it induces sneezing and so, it is used to relieve nasal congestion, especially during coughs and colds.

\section{Cephaelis ipecacuanha}

Medicinal value: Powdered leaves are used in case of dysentery. Decoction of leaf is used as an expectorant. It is applied externally on the site of bites by the venomous insects and scorpions.

\section{Chenopodium album}

Medicinal value: Whole shoot is cooked and used in case of spleen diseases bile and pectoral disorders. Leaves are rich in vitamin A and vitamin C. It improves appetite and used as anthelmentic agent. The tribals used the decoction of leaves to expel dead fetus.

Other uses: Green leaves and upper part of the plants are used as vegetable called "Sag".

\section{Chlorophytum arundinaceum}

Medicinal Value: Roots are used to cure impotency, diabetes and arthritis. It is also used to increase body immunity. Root powdered fried in the ghee is used in case of problems of mouth and throat. It is also used to cure natural and post natal problems. It is considered as alternative to viagra.

\section{Cinnamomum glaucescens}

Medicinal Value: Pericarp of fruit is used in making medicine and perfumes. Oil extracted from the pericarp or bark acts as natural analgesic and also anti microbial in nature. The leaf juice is applied on wound.

Other use: Wood is used in making furniture.

\section{Cinnamomum tamala}

Medicinal Value: Decoction of leaves and bark is used in the treatment of bladder disorders, dryness of mouth, diarrhea, and nausea.

Other Uses: Bark and leaves are used as flavoring agent.

\section{Cinnamomum camphora}

Medicinal value: Leaves show analgesic effect for pain relieving, sore muscles, low back pain, and arthritic pain. People use leaf juice tropically to relief pain and reduce itching. It has also been used to treat fungal infection of the toe nail, warts, and cold.

\section{Cissampelos pareira}

Medicinal value: Decoction of leaves is used to treat problems related to female reproductive system. It maintains hormonal balance, prevents miscarriage, eases child birth and reduces problems of menstruation excessive bleeding and uterine hemorrhage in females. 


\section{Cleistocalyx operculata}

Medicinal value: The leaves and buds are harvested, dried and used as herbal tea. It is used by tribals for the treatment of gastric ailments. Root decoction is used to treat hepatitis and bark decoction is used in leprosy.

\section{Clerodendrum viscosum}

Medicinal value: The leaves and root are used as herbal remedy for alopecia, asthma, cough, diarrhea, rheumatism, and fever and skin diseases. The decoction of root $\&$ bark of this plant is given in the dose twice daily for respiratory disease, fever, periodic fever, cough and asthma.

\section{Colebrookea oppositifolia}

Medicinal value: Leaves are used to treat wounds and fracture. Roots are used in epilepsy. Oil possesses fungi toxic property. Leaf juice is used to treat fever, headache and dysentery.

Other uses: Plant is also used as fodder. The branches are dried and used as fuel.

\section{Curcuma amada}

Medicinal value: Dry Rhizome powder is useful in lowering the blood cholesterol. It is also used in the treatment of cough, cold and testicle swelling.

Other uses: The fresh and dried rhizomes are used for flavoring curries.

\section{Curcuma angustifolia}

Medicinal value: Rhizome is used to heal peptic ulcers. It is beneficial for the treatments of dysentery, diarrhea and colitis. Leaves are used as antibacterial agents.

Other uses: It is the source of nutrition and as a nonirritating diet for patient suffering from specific chronic ailments, recovering from fever. Its drink is also used as a replacement of breast milk

\section{Curcuma aromatica}

Medicinal Value: Rhizome is used to treat psoriasis, eczema, acne and other inflammatory skin condition. It improves gall bladder function. It is used in remedy for anemia and menstrual cramps.

\section{Cuscuta reflexa}

Medicinal value: The rural people use the juice of this plant for treating jaundice and its warm paste is applied in rheumatism, gout and other affected parts of the body. The juice of the plant mixed with the juice of Saccharum officinarum is used in the treatment of jaundice. It also used to treat the range of impotence, premature ejaculation, frequent urination, ringing in the ears, lower back pain, white discharge from the vagina.

\section{Cutleya spicata}

Medicinal value: Leaf decoction is used in asthma bronchitis, catarrh, and sinusitis. For female health, it also helps to stop the flow of heavy bleeding and leucorrhoea and releases urine retention. 


\section{Cympogon winterianus}

Medicinal value: Its leaves have anti- inflammatory and antioxidant properties. It produces oil by steam distillation method.

Other uses: Citronella oil is commercially used as mosquito repellants and household fumigants. Oil is also used as food flavoring agent in beverages, baked goods, candies, dairy products.

\section{Cynodon dactylon}

Medicinal value: Doob grass is used in different traditional medicines. It is crushed and applied on the bleeding on the cutting. Its pest is also used on wounds. People suffering from eye disease are advised to walk on dense mat of doob grass by bare foot.

Other uses: This plant is used in different kinds of worship ceremony. Almost all kinds of worship is completed with the offering of the doob grass.

\section{Cyperus rotundus}

Medicinal value: Roasted tuber is used to treat wounds and other skin disease. Tuber is used to stop tooth decay. It is also used to treat pain and muscles relaxation.

Other uses: This plant is used as fodder for cattle. Although tubers are bitter in taste but is has good nutritional value.

\section{Dalbergia latifolia}

Medicinal value: Leaf is used in dyspepsia, diarrhea also in obesity and leprosy. Leaf extract possessed significant anti-inflammatory activity without any side effect,

Other uses: The tree produces hard, durable, heavy wood resistant to rot and insects. Wood from the tree is used in premium furniture making and cabinetry.

\section{Delonix regia}

Medicinal value: Decoction of the leaves is used in the treatment of gastric problems, body pain, and rheumatic pain of joints and to cure malaria.

\section{Desmodium gangeticum}

Medicinal Value: The root is given to improve digestive system in case of dysentery. The extract of roots is used in the preparation of Dasmularisht an important ayurvedic medicine. It is also used to cure allergic and inflammatory symptom. It is also used to improve memory and to cure alzimers disease.

\section{Desmostachya bipinnata}

Medicinal value: Roots are used against loose motion and retention of urine. In case of loose motion local people boil flowers and filter it. From the filtrate they take $15-20 \mathrm{ml}$ per day 3 times for three days. 
Other uses: The mature plant is harvested and from the dried leaves mat is prepared. It is planted as soil binder on the bank of the canal or the road side. It is considered to be a secret plant by the Buddhist and Hindus. They used to sit on it during meditation or worship.

\section{Eclipta prostrata}

Medicinal value: Leaf decoction with cow milk relieves acidity. This plant helps in the treatment of alopecia jaundice, fatty liver, loss of appetite, palpitation of heart, pimples, premature graying of hair. Leaf paste is externally used in eczema for 15 days. Gargling with leaf juice strengthens teeth and gums and clears coating of the tongue. The equal ratio of powder of leaves of Eclipta prostrata, Leucas aspera, and Phyllanthus niruri are mixed with butter milk and taken orally to cure jaundice.

\section{Eugenia jambolana}

Medicinal value: Leaves and bark are used in case of blood pressure. The fruit is also used in dysentery, diarrhea, piles and stomachache. The powder of the seed greatly reduces the blood sugar.

Other uses: Main trunk is used for the preparation of boat and several other household materials. Carpenters use it as alternative of teak. It is a very good shade tree. The green leaves are used as the fodder.

\section{Eulaliopsis binata}

Medicinal value: Plant is burnt and ash is mixed with mustard oil is applied to treat cuts and wounds of domestic animals.

Other uses: It is used as natural fiber. The fiber is made from the leaf. It is widely collected for making paper, string and mats

\section{Euphorbia hirta}

Medicinal value: It has curative effect on dengue patient. It is used to reduce body temperature. It reduces the thirst among the thirsty People. The tribal apply the milky latex on the skin to cure rashes. The paste of the leaves is given to women suffering from leucorrhea. It is also used in family planning because its continuous consumption causes infertility of male. Root decoction is used against snake bite.

\section{Ficus auriculata}

Medicinal value: Latex obtained from plant is used to treat diarrhea, dysentery. The latex is applied to cuts and wounds.

Other uses: The leaves are used as fodder. The fruits are used in Salad and in the preparation of pickle.

\section{Terminalia bellirica}

Medicinal value: It is one of constituent of "Triphala churna" powder. Fried pieces of fruit are used in cold, cough, asthma and voice problem. Fruit powder is tonic, digestive and used to cure asthma and bronchitis. Seeds are also used in bronchitis. Mixture of its bark clove and honey relief diarrhea. Equal ratio of mixture of fruit powder and sugar helps to 
increase vision power of eyes.

Other uses: Leaves are used as a good fodder for the herbivores. Gum is obtained from bark.

\section{Terminalia chebula}

Medicinal value: It is one of constituent of "Triphala churna". Bark is diuretic and cardiotonic. Powder of bark is used as tooth powder. Unripe fruit is used in diarrhea and dysentery. Fruit powder when taken with warm water cures cough. It is also used in urinary disorders, vomiting, and constipation and also applied locally on wounds or ulcers to cure it.

Other use: Gum is extracted from the bark.

\section{Terminalia tomentosa}

Medicinal value: The bark is astringent and used in the form of decoction to treat diarrhea and ulcers.

Other uses: The wood is used for making furniture. Bark is used for dying black color and it yields gum which is used in making incense and cosmetics.

Data obtained from the field survey are presented in table 1. Diseases like eye problems, syphilis, toothache, burning sensation in legs, spleen diseases, arthritis, diabetes, jaundice,dysentery, skin diseases, leucorrhoea, malaria, high blood pressure, venereal diseases, arthritis, rheumatism, meningitis, asthma, insomnia, nervous diseases, joints problems, paralysis, fever, cough and cold, abdominal pain, liver and spleen problems, leprosy, leucoderma, alzimers, sore throat, constipation, gastrointestinal disorders impotency, epilepsy were found to be treated with these plants.

Out of total plants studied, depending upon the habit, 25 plants (46\%) were herbs, 22 plants $(41 \%)$ were trees, 5 plants (9\%) were shrubs and 2 plants (4\%) were climbers (fig. 2 ). Similarly ,leaves of 32 plants, root of 16 plants, bark of 12 plants, fruits of 10 plants, seed of 7 plants, flower of 6 plants, shoot of 4 plants, stem of 4 plants, gum of 4 plants, rhizome of 3 plants, latex of 2 plants and tuber of 1 plant were used for different purposes (fig.3). From the total studied plants 35 plants were used only for medicinal purposes, 18 plants are used for medicinal and other purposes whereas only one plant was used in making rope. The 18 plants used for medicine and other purposes were food (5 plants), as furniture (4 plants), as flavoring (3 plants), gum ( 2 plants), ornaments ( 2 plants), herbal tea (1 plant), as narcotic (1 plant), coloring (1 plant) and for making mat only one plant (fig.4).

Although, many researchers from Nepal and India have mentioned the ethanobotanical uses of the many plants included in this study. Manandhar (1986) carried out ethnobotanical study of Mooshar tribes of Dhanusha district, Nepal. Altogether 189 species of the economically as well as ethnobotanically important plants have been reported from Royal Bardia National Park, Nepal by Ghimire et al. (2000). Altogether 150 medicinal plant species are described with their botanical name, Nepali name, short taxonomic description and uses (IUCN-Nepal, 2000). But, the present study reports many new ethnomedicinal uses of the same plants which were not mentioned in previous works. 
Ahmad et.al. (2012) reported Aloe vera used for the treatment of diabetes from district Attock (Pakistan), Aegle marmelos used by the Ahoms in upper Assam, India for piles (Bailung, 2016). Present study found the use of this plant in diarrhea, dyspepsia and burning sensation of feet.Cassia fistula for rheumatism and respiratory diseases in Tehrathun district, eastern Nepal (Rai, 2003) was documented in traditional medicine. Similarly, Achyranthes aspera for asthma,Terminalia bellirica for cough and cold, and T. chebula for cough, cold and respiratory problems, Azadirachta indica for skin problems and as anthelmintic, Bombax ceiba for wound, Cenopodium album to regulate blood pressure were documented to be used in eastern part of Parsa district (Yadav, 1999). Achyranthes aspera recorded to be used for toothache and asthma in Terai forest of western Nepal (Singh et.al., 2012) and the present study found to be used for abortion and induction of labor pain.

Amaranthus spinosus in leucorrhoea and colic pain, Acacia catechu in toothache, intestinal pain and in skin diseases, Azadirachta indica in diabetes and skin problems, Bombax ceiba as antidysentric, Chenopodium album as anthelmintic, Curcuma amada in rheumatism, Eclipta prostrata in wound and skin diseases, Cuscuta reflexa in fever and rheumatism were recorded to be used in traditional medicine (Singh, 2015). An ethnobotanical investigation among tribes in Madurai district of Tamilnadu, India, recorded use of Andrographis paniculata in excessive bleeding during menstruation and Terminalia chebula in fever (Ignacimuthu, 2006). Another similar study on medicinal plants used by traditional users in Villupuram district of Tamil Nadu, India, described use of Boerhaavia diffusa in spleen enlargement and Cynodon dactylon in blood vomiting (Sankaranarayanan, 2010).

Present study found use of the studied plants in many new health problems. Like, Acacia Arabica in gonorrhea, Achyranthes aspara in induction of labour pain, Adina cardifolia in headache, Albizia lebbeck in leprosy, Aloe vera to promote hair growth, Amaranthus spinosus to check internal bleeding, Azadirachta indica in urinary problem, Bombax ceiba in impotence, Bauhinia purporea in hormonal imbalance, Butea monosperma in ulcer, Chenopodium album in spleen and bile diseases, Clerodendrum viscosum in respiratory problems, Curcuma angustifolia in peptic ulcer, Cuscuta reflexa in jaundice, Cyperus rotundus in muscular pain, Eclipta prostrata in jaundice and fatty lever, Terminlia bellirica in to enhance eye vision, Terminalia chebula in vomiting and constipation, Terminalia tomentosa in diarrhea and ulcer. 


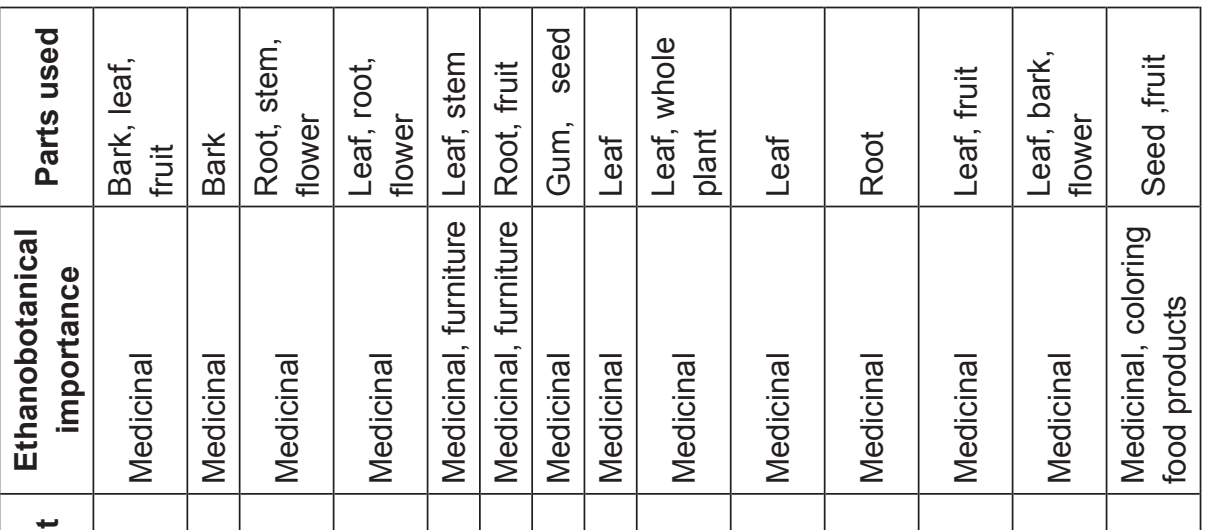

흥

竞

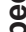

竞

एँ

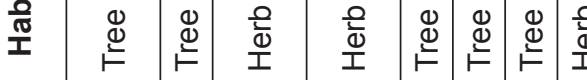

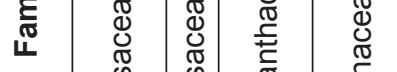

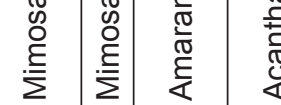

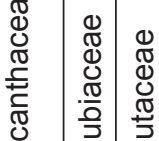

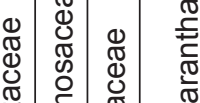

ह

密

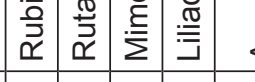

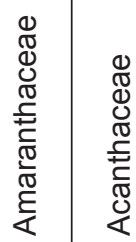

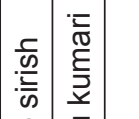

产

要

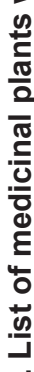

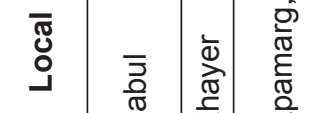<smiles>CCCC</smiles>

(2) 


\begin{tabular}{|c|c|c|c|c|c|c|c|c|c|c|c|c|c|c|}
\hline 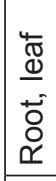 & 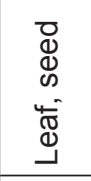 & 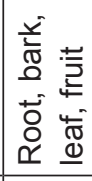 & 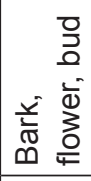 & $\begin{array}{l}\bar{\Phi} \\
\mathbb{\infty} \\
心\end{array}$ & $\begin{array}{l}\stackrel{4}{\mathbb{\sigma}} \\
\stackrel{\Xi}{\Xi}\end{array}$ & \begin{tabular}{|l}
$\bar{\Phi}$ \\
$\sum_{0}$ \\
$\underline{L}$ \\
\end{tabular} & 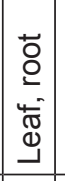 & 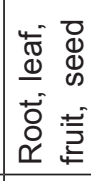 & 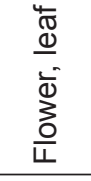 & 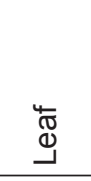 & 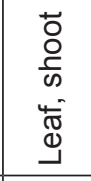 & 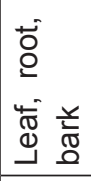 & 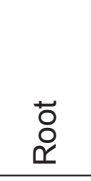 & 蒙 \\
\hline $\begin{array}{l}\overline{8} \\
\frac{0}{2} \\
\bar{\pi} \\
. \frac{0}{0} \\
\frac{0}{0} \\
\frac{0}{2} \\
\sum\end{array}$ & 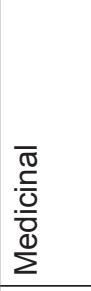 & 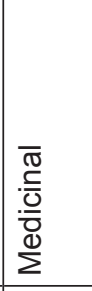 & 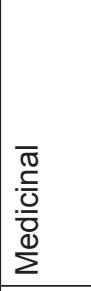 & $\begin{array}{l}\overline{\widetilde{\pi}} \\
. \frac{\mathrm{C}}{0} \\
\frac{\mathrm{O}}{\overline{0}} \\
\stackrel{0}{\Sigma}\end{array}$ & 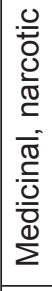 & $\begin{array}{l}\overline{8} \\
0 \\
0.0 \\
\overline{0} \\
. \overline{0} \\
\frac{0}{0} \\
\frac{0}{2} \\
\Sigma\end{array}$ & \begin{tabular}{|l|}
$\bar{\pi}$ \\
.$\overline{\frac{C}{0}}$ \\
.$\overline{0}$ \\
$\frac{\mathbb{d}}{\Sigma}$ \\
\end{tabular} & 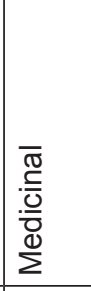 & $\begin{array}{l}\bar{\pi} \\
\frac{\bar{C}}{0} \\
\frac{0}{0} \\
\frac{0}{2} \\
\end{array}$ & $\begin{array}{l}\bar{\pi} \\
\frac{\bar{\sigma}}{0} \\
\frac{0}{0} \\
\stackrel{\Phi}{\Sigma} \\
\end{array}$ & 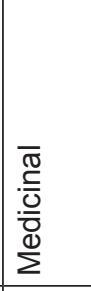 & 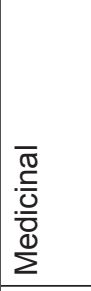 & 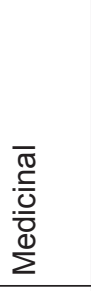 & 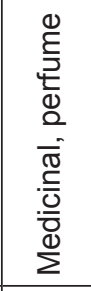 \\
\hline$\frac{0}{\frac{0}{1}}$ & $\begin{array}{l}\frac{0}{ \pm} \\
\text { đ }\end{array}$ & $\stackrel{\bigotimes}{\stackrel{\infty}{\varrho}}$ & 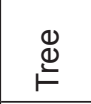 & $\begin{array}{l}\frac{0}{2} \\
\frac{2}{\omega}\end{array}$ & $\begin{array}{l}\frac{0}{0} \\
\text { I }\end{array}$ & 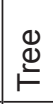 & $\begin{array}{l}\frac{0}{2} \\
\frac{2}{\omega} \\
\frac{c}{n}\end{array}$ & 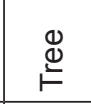 & $\begin{array}{l}\text { 응 } \\
\text { 인 }\end{array}$ & 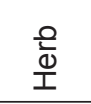 & $\begin{array}{l}\frac{0}{0} \\
\frac{0}{1}\end{array}$ & $\begin{array}{l}\text { 을 } \\
\frac{2}{2} \\
\infty\end{array}$ & 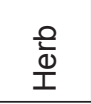 & 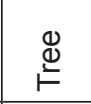 \\
\hline 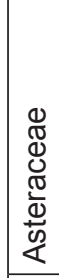 & 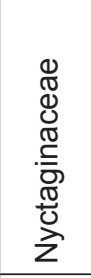 & 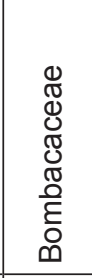 & 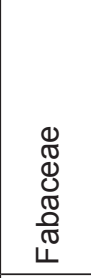 & 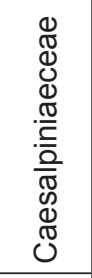 & 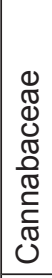 & 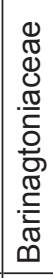 & 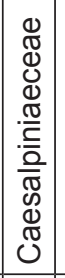 & 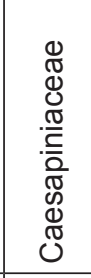 & 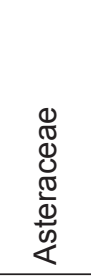 & 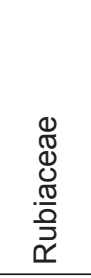 & 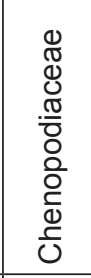 & 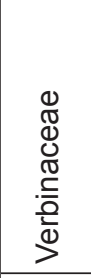 & 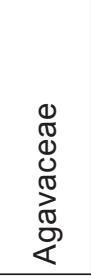 & 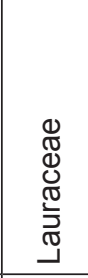 \\
\hline 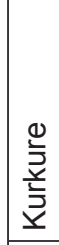 & $\begin{array}{l}\frac{\pi}{\pi} \\
\stackrel{0}{5} \\
\frac{1}{\pi} \\
\stackrel{0}{J} \\
0 \\
\end{array}$ & $\begin{array}{l}\overline{\widetilde{N}} \\
\text { है } \\
\bar{\omega}\end{array}$ & $\begin{array}{l}\frac{\pi}{\pi} \\
\frac{\pi}{\pi} \\
\square\end{array}$ & 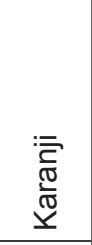 & \begin{tabular}{|l|}
$\frac{D}{\sigma}$ \\
$\frac{\sigma}{\sigma}$ \\
$\frac{\sigma}{\infty}$
\end{tabular} & 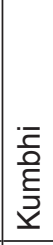 & \begin{tabular}{|l|}
$\vec{\pi}$ \\
$\alpha$ \\
$\tilde{\sigma}$ \\
0 \\
0
\end{tabular} & 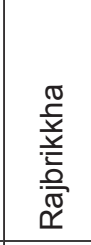 & $\begin{array}{l}\frac{1}{0} \\
\frac{0}{5} \\
\frac{1}{2} \\
\frac{1}{0} \\
\frac{1}{0} \\
\frac{\pi}{4} \\
\end{array}$ & 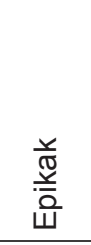 & $\begin{array}{l}\stackrel{\oplus}{ \pm} \\
\stackrel{\varpi}{\varpi} \\
\infty\end{array}$ & $\begin{array}{l}\overrightarrow{\frac{T}{T}} \\
\frac{\mathbb{T}}{\Phi} \\
\end{array}$ & 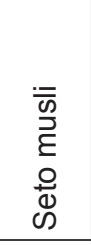 & 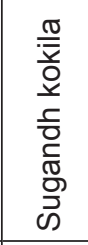 \\
\hline 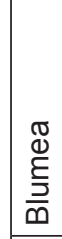 & $\begin{array}{l}\overline{0} \\
\Phi \\
\$ \\
3 \\
0 \\
\text { 우 }\end{array}$ & 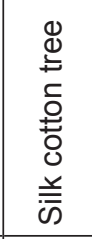 & 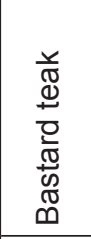 & 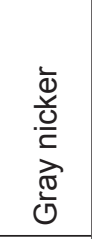 & 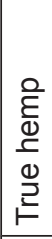 & 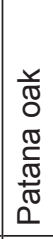 & 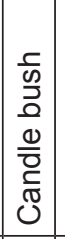 & 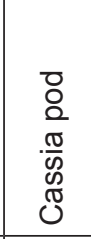 & 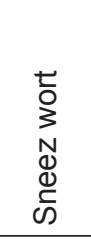 & 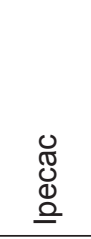 & $\begin{array}{l}\square \\
\stackrel{0}{0} \\
0 \\
0 \\
0 \\
0 \\
0\end{array}$ & $\begin{array}{l}\stackrel{\mathbb{0}}{\leftarrow} \\
\underset{\mathbb{N}}{\mathbb{N}} \\
0\end{array}$ & 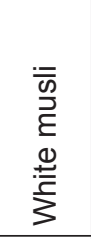 & 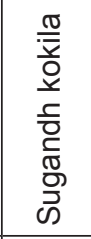 \\
\hline 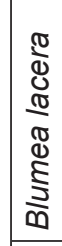 & 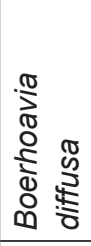 & 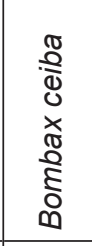 & 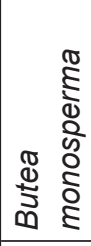 & 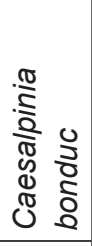 & 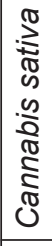 & 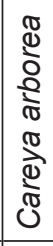 & \begin{tabular}{|c|}
$\frac{\pi}{\pi}$ \\
$\frac{\pi}{\pi}$ \\
.$\frac{\pi}{\omega}$ \\
$\tilde{D}$ \\
$\tilde{0}$ \\
0
\end{tabular} & 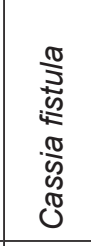 & 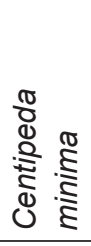 & 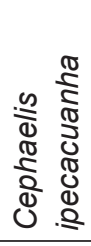 & 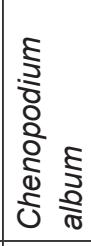 & 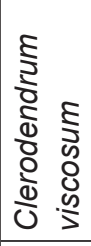 & 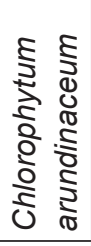 & 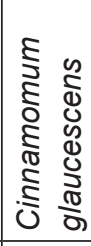 \\
\hline$\stackrel{2}{2}$ & $\stackrel{\varphi}{\sim}$ & 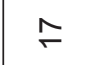 & $\stackrel{\infty}{\sim}$ & $\stackrel{9}{\longrightarrow}$ & $\widetilde{N}$ & N & $\mathbf{N}$ & $\stackrel{\sim}{N}$ & $\stackrel{\sim}{\sim}$ & $\stackrel{\llcorner}{\sim}$ & $\widetilde{N}$ & $\hat{N}$ & $\stackrel{\infty}{N}$ & $\tilde{N}$ \\
\hline
\end{tabular}




\begin{tabular}{|c|c|c|c|c|c|c|c|c|c|c|c|c|c|}
\hline 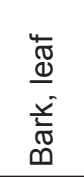 & 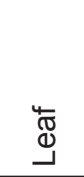 & 离 & 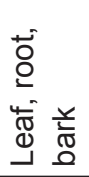 & 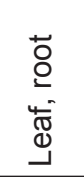 & $\begin{array}{l}\stackrel{0}{E} \\
\frac{N}{0} \\
\frac{N}{\Sigma}\end{array}$ & $\begin{array}{l}\stackrel{0}{E} \\
\stackrel{N}{N} \\
\frac{\bar{N}}{\alpha}\end{array}$ & $\begin{array}{l}\stackrel{\varrho}{E} \\
\stackrel{N}{N} \\
\frac{N}{\alpha}\end{array}$ & $\frac{\frac{E}{\Phi}}{\stackrel{D}{\omega}}$ & $\begin{array}{c}4 \\
\mathbb{J} \\
\mathbb{1} \\
\end{array}$ & 㐫 & $\stackrel{\sqrt[4]{\mathbb{\sigma}}}{\Phi}$ & 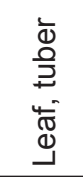 & $\begin{array}{l}\frac{\hbar}{\frac{C}{0}} \\
\frac{0}{2} \\
\frac{0}{0} \\
\frac{}{3}\end{array}$ \\
\hline $\begin{array}{l}\overline{\frac{\pi}{T}} \\
\frac{\overline{0}}{\overline{0}} \\
\frac{\mathrm{d}}{2} \\
\sum\end{array}$ & $\begin{array}{l}\bar{\pi} \\
\frac{\bar{C}}{0} \\
\frac{0}{0} \\
\stackrel{D}{2}\end{array}$ & 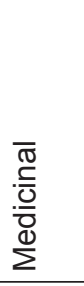 & 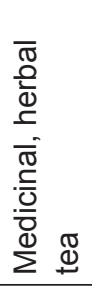 & 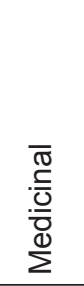 & 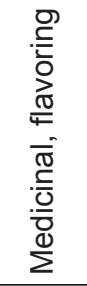 & 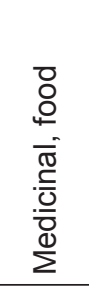 & $\begin{array}{l}\overline{\bar{\sigma}} \\
. \frac{.}{0} \\
. \frac{0}{0} \\
\frac{0}{2} \\
\Sigma\end{array}$ & $\begin{array}{l}\overline{\mathbb{N}} \\
. \frac{\mathrm{C}}{0} \\
. \frac{0}{0} \\
\frac{\mathbb{D}}{\Sigma}\end{array}$ & 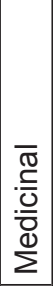 & 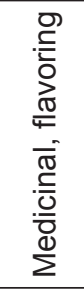 & $\begin{array}{l}\frac{1}{0} \\
\frac{0}{0} \\
\frac{0}{0} \\
\bar{\pi} \\
\frac{.0}{0} \\
\cdot \frac{0}{0} \\
\frac{0}{2}\end{array}$ & 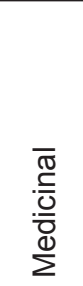 & 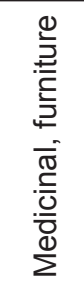 \\
\hline 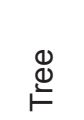 & $\stackrel{\bigotimes}{\stackrel{\Phi}{\Perp}}$ & 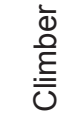 & 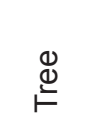 & $\begin{array}{l}\frac{0}{2} \\
\frac{2}{\omega}\end{array}$ & 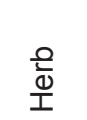 & $\begin{array}{l}\frac{0}{\frac{1}{d}} \\
\text { I }\end{array}$ & $\begin{array}{l}\frac{0}{\frac{1}{d}} \\
\text { I }\end{array}$ & 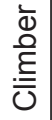 & $\frac{\text { 은 }}{\frac{1}{1}}$ & $\begin{array}{l}\frac{0}{\frac{1}{d}} \\
\text { I }\end{array}$ & 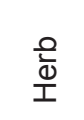 & $\begin{array}{l}\frac{0}{\frac{1}{d}} \\
\text { I }\end{array}$ & $\stackrel{\Phi}{\stackrel{\Phi}{\Perp}}$ \\
\hline 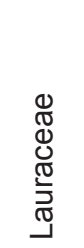 & 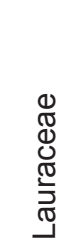 & 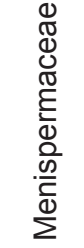 & 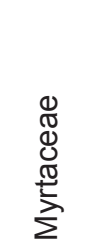 & 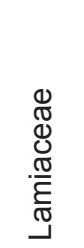 & 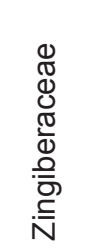 & 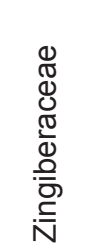 & 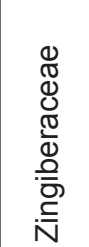 & $\begin{array}{l}0 \\
\mathbb{0} \\
0 \\
0 \\
0 \\
\mathbb{0} \\
7 \\
\geq \\
0 \\
\geq \\
0 \\
0\end{array}$ & 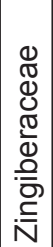 & $\begin{array}{l}\mathbb{1} \\
\mathbb{d} \\
\mathbb{0} \\
0 \\
\mathbb{D} \\
0 \\
0\end{array}$ & $\begin{array}{l}\mathbb{0} \\
\mathbb{0} \\
\mathbb{0} \\
\mathbb{\pi} \\
0 \\
0\end{array}$ & 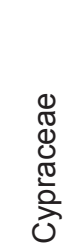 & 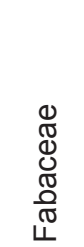 \\
\hline 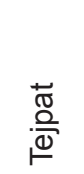 & $\begin{array}{l}\frac{0}{0} \\
\frac{0}{2}\end{array}$ & 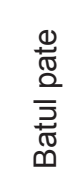 & 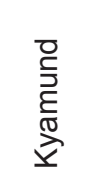 & 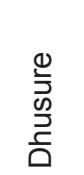 & $\begin{array}{l}\frac{\overline{0}}{\frac{0}{0}} \\
\frac{\bar{C}}{\sqrt{0}} \\
\frac{E}{\sqrt{0}} \\
\frac{1}{4}\end{array}$ & $\begin{array}{l}\frac{0}{0} \\
\frac{d}{\sqrt{0}} \\
\frac{0}{c} \\
\frac{0}{\sqrt[T]{0}}\end{array}$ & 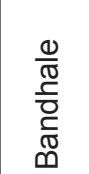 & 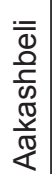 & $\begin{array}{c}\frac{0}{\sqrt{0}} \\
\frac{\mathscr{S}}{\frac{1}{\sigma}} \\
\frac{\sigma}{0} \\
0 .\end{array}$ & 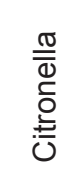 & $\begin{array}{l}\text { 응 } \\
\text { هั }\end{array}$ & 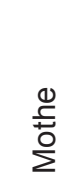 & $\begin{array}{l}\overline{\mathbb{N}} \\
\stackrel{\mathscr{D}}{\mathbb{N}} \\
\stackrel{\mathscr{N}}{0}\end{array}$ \\
\hline 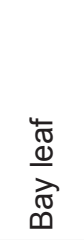 & 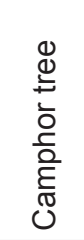 & $\begin{array}{l}\frac{\pi}{3} \\
\text { 茓 }\end{array}$ & 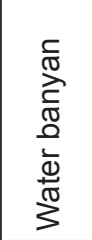 & 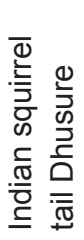 & 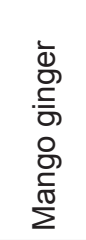 & 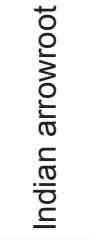 & $\begin{array}{l}\frac{0}{\frac{0}{0}} \\
\frac{E}{0} \\
\frac{5}{ \pm} \\
\frac{0}{3}\end{array}$ & $\begin{array}{l}\frac{1}{0} \\
\frac{0}{0} \\
\frac{0}{0}\end{array}$ & 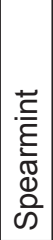 & $\begin{array}{l}\frac{\sigma}{\bar{\sigma}} \\
\frac{0}{0} \\
\stackrel{ \pm}{0}\end{array}$ & $\begin{array}{l}\mathscr{D} \\
\frac{0}{0} \\
\frac{\pi}{0}\end{array}$ & 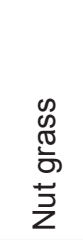 & $\begin{array}{l}\text { D } \\
0 \\
3 \\
0 \\
0 D \\
0 \\
\propto 1\end{array}$ \\
\hline 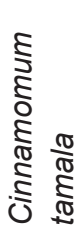 & 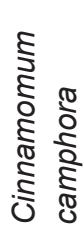 & 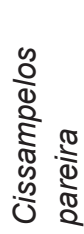 & 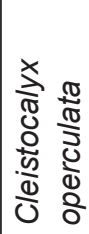 & 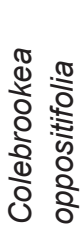 & 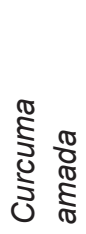 & 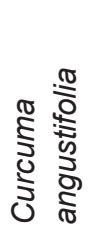 & 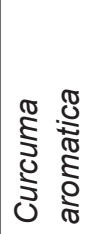 & 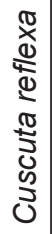 & 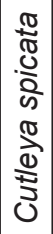 & 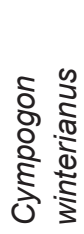 & 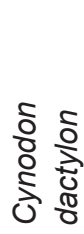 & 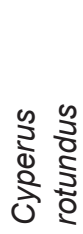 & 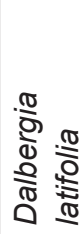 \\
\hline ㅇ & $\bar{m}$ & ले & $m$ & ウ & ल & 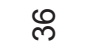 & $\hat{m}$ & $\infty$ & m & 寸 & ซ & $\underset{\forall}{\mathscr{V}}$ & $\stackrel{\mathscr{f}}{\forall}$ \\
\hline
\end{tabular}




\begin{tabular}{|c|c|c|c|c|c|c|c|c|c|c|}
\hline 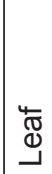 & $\begin{array}{l}\overrightarrow{0} \\
\mathbb{\Upsilon}\end{array}$ & 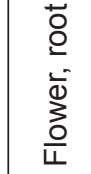 & 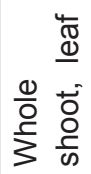 & 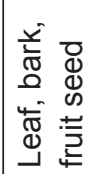 & 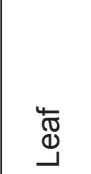 & 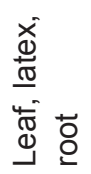 & 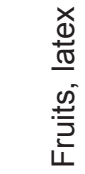 & 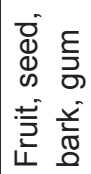 & 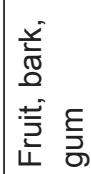 & 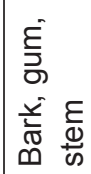 \\
\hline $\begin{array}{l}\overline{\overline{0}} \\
. \frac{\mathrm{C}}{\mathrm{O}} \\
\frac{\overline{0}}{\mathrm{O}} \\
\frac{\mathrm{d}}{\Sigma}\end{array}$ & $\begin{array}{l}\overline{\overline{0}} \\
. \frac{\mathrm{C}}{\mathrm{O}} \\
\overline{\mathrm{O}} \\
\overline{\mathrm{d}} \\
\Sigma\end{array}$ & 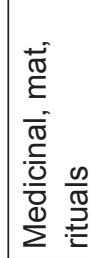 & $\begin{array}{l}\overline{\widetilde{O}} \\
\frac{\bar{C}}{\mathrm{U}} \\
\frac{\mathrm{O}}{0} \\
\frac{0}{2}\end{array}$ & \begin{tabular}{|l}
$\overline{\widetilde{J}}$ \\
$\frac{\mathrm{C}}{\overline{0}}$ \\
$\frac{\mathrm{O}}{\overline{0}}$ \\
$\stackrel{\mathbb{0}}{\Sigma}$ \\
\end{tabular} & 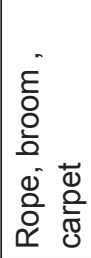 & 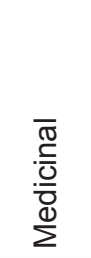 & 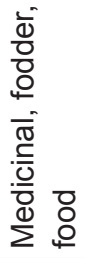 & 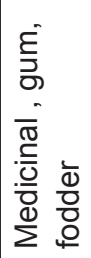 & $\begin{array}{l}\frac{E}{5} \\
0 \\
\overline{0} \\
. \overline{0} \\
\frac{\overline{0}}{0} \\
\sum \\
\sum\end{array}$ & 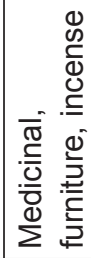 \\
\hline 导 & $\begin{array}{l}\text { 을 } \\
\text { c }\end{array}$ & $\begin{array}{l}\frac{0}{0} \\
\frac{1}{1}\end{array}$ & $\begin{array}{l}\frac{0}{0} \\
\frac{1}{I}\end{array}$ & $\stackrel{\bigotimes}{\stackrel{\Xi}{\Perp}}$ & $\begin{array}{l}\frac{0}{0} \\
\frac{1}{1}\end{array}$ & $\frac{\frac{0}{0}}{\frac{1}{I}}$ & $\stackrel{\bigotimes}{\stackrel{\bigotimes}{\Perp}}$ & $\stackrel{\bigotimes}{\stackrel{\Phi}{\models}}$ & 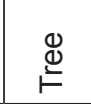 & 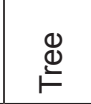 \\
\hline $\begin{array}{l}0 \\
\mathbb{8} \\
\mathbb{8} \\
0 \\
\mathbb{0} \\
\mathbb{0} \\
\mathbb{0} \\
\stackrel{1}{1} \\
\end{array}$ & $\begin{array}{l}\mathbb{1} \\
\mathbb{\Xi} \\
\mathbb{0} \\
\mathbb{\pi} \\
\mathbb{0} \\
\mathbb{1} \\
\end{array}$ & $\begin{array}{l}\mathbb{1} \\
\mathbb{0} \\
\mathbb{d} \\
0 \\
\mathbb{0} \\
0 \\
\end{array}$ & 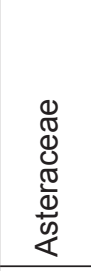 & 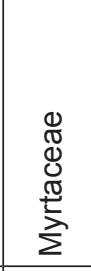 & $\begin{array}{l}\mathbb{0} \\
\mathbb{\pi} \\
\mathbb{0} \\
0 \\
0 \\
0 \\
0 \\
\end{array}$ & 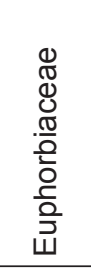 & $\begin{array}{l}0 \\
\mathbb{J} \\
0 \\
0 \\
\pi \\
\vdots \\
\Sigma\end{array}$ & 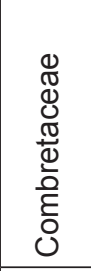 & 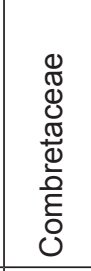 & 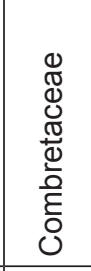 \\
\hline 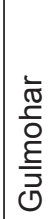 & 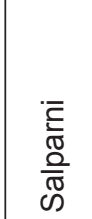 & $\begin{array}{l}\frac{5}{\omega} \\
\frac{1}{2}\end{array}$ & 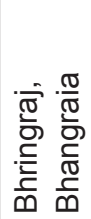 & 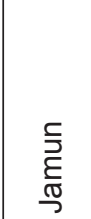 & 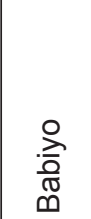 & $\begin{array}{l}\frac{\overline{0}}{\frac{.}{0}} \\
\frac{8}{0} \\
\frac{0}{0} \\
0\end{array}$ & $\begin{array}{l}\frac{O}{\bar{\sigma}} \\
\stackrel{\text { E }}{Z}\end{array}$ & $\stackrel{\circ}{\stackrel{\circ}{5}}$ & $\begin{array}{l}\text { 온 } \\
\text { 소 }\end{array}$ & 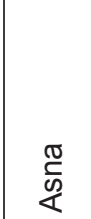 \\
\hline 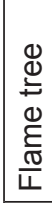 & 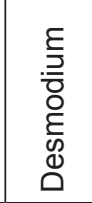 & 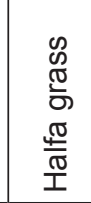 & 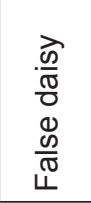 & 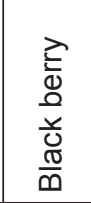 & $\begin{array}{l}\infty \\
0 \\
0 \\
\pi \\
0 \\
\bar{\pi} \\
\bar{\pi} \\
\frac{\pi}{\pi} \\
\infty\end{array}$ & 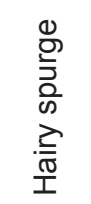 & 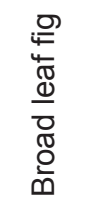 & 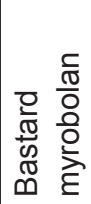 & 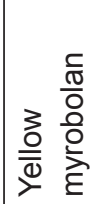 & 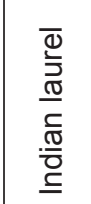 \\
\hline 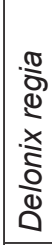 & 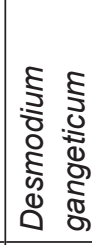 & 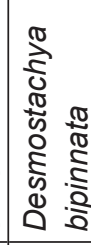 & 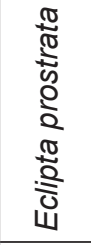 & 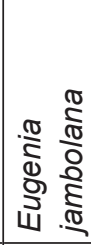 & 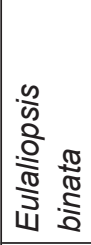 & 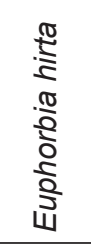 & 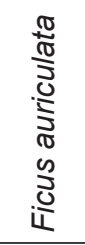 & 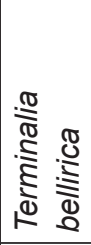 & 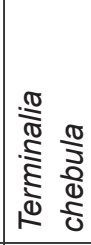 & 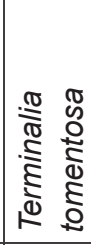 \\
\hline & $\stackrel{5}{7}$ & $\stackrel{0}{+}$ & 守 & $\stackrel{\infty}{+}$ & \& & 이 & is & กิ & గి & 10 \\
\hline
\end{tabular}




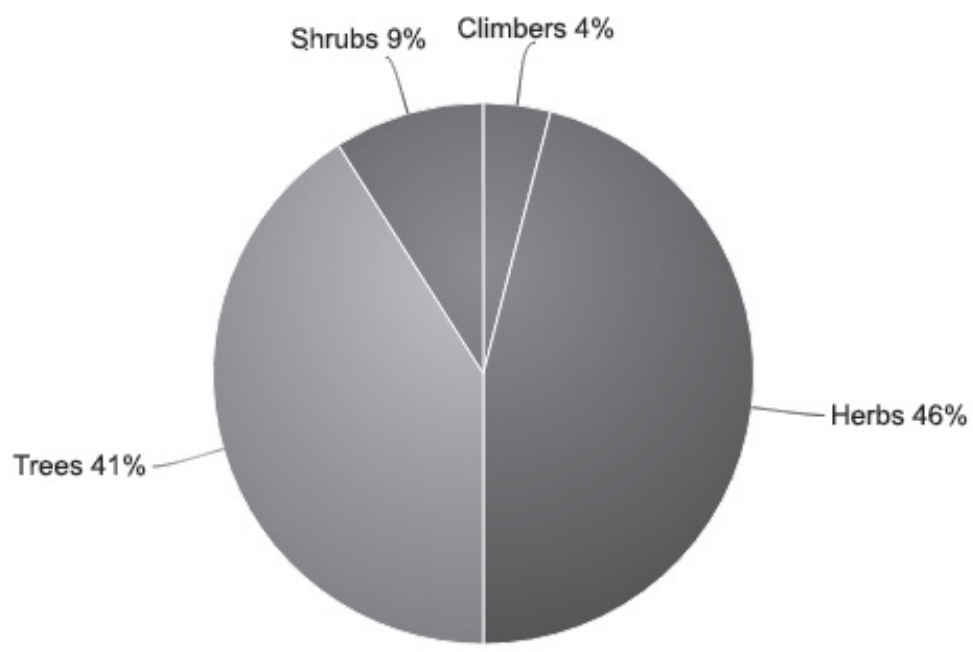

FIG. 2. Proportion of total plant species based upon their habits.

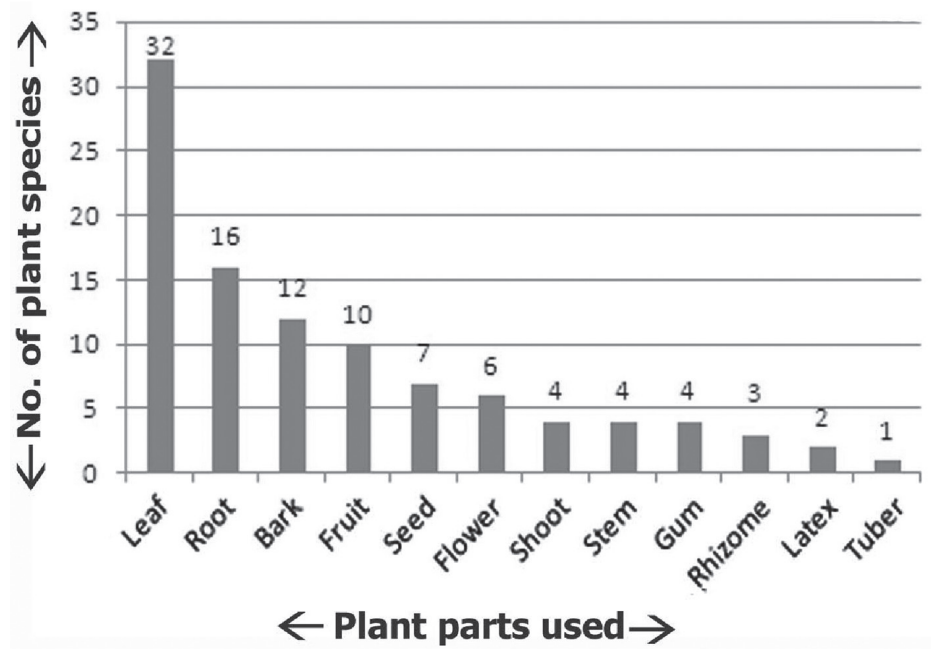

FIG. 3. Utilization pattern of different parts of plants. 


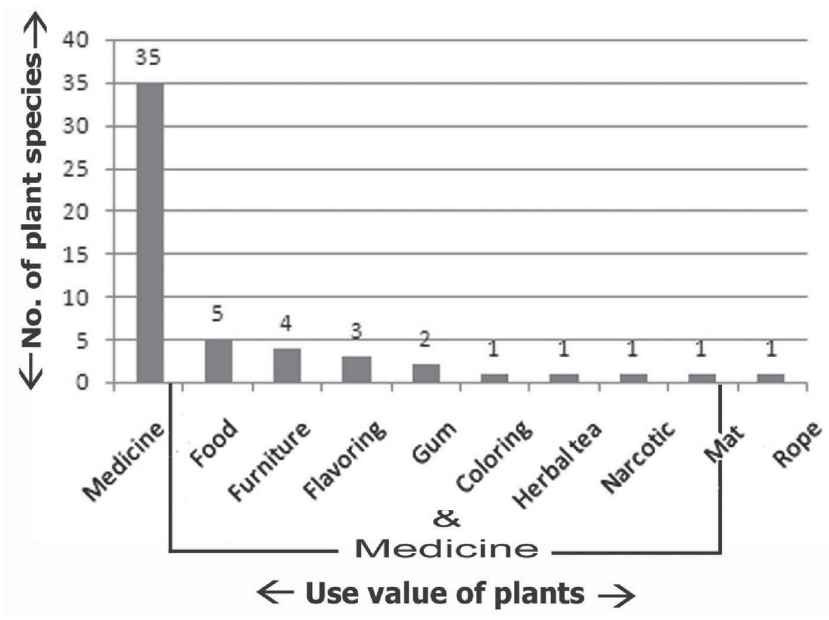

\section{FIG. 4. Number of plant species according to their use.}

This study reveals that knowledge and uses of herbal medicines for the treatment of various diseases among the Tharu community of Parsa district is still a major part of their life and culture. They use these plants not only for the medicinal purposes but also for other purposes. The result of the present study provides evidence that these herbs play important role in the healthcare and social life of this tribal community. Documentation of these plants play great role in the biodiversity conservation and asset for the future generation.

\section{ACKNOWLEDGEMENTS}

This paper is part of $\mathrm{PhD}$ thesis of the author. The author extends sincere gratitude to the ethnic community and local people of the VDCs of the Parsa district for their generous cooperation during field study. The D.F.O., Forest officer of the district are acknowledged for facilitating the field trips. Similarly, local traditional healers are also acknowledged for providing valuable information.

\section{REFERENCES}

AHMAD, M; QURESHI, R; ARSAD, M; ZAFAR, M (2012) Traditional herbal remedies used for the treatment of diabetes from district Attock, Pakistan. J. Pakistan journal of Botany 6: 2777-2782.

BAILUNG,B; PUZARI, M ( 2016) Traditional use of plants by the Ahoms in human health management in upper Assam, India. J. Medicinal Plant Studies 2: 48-51.

CHAUDHARY, R P (1998) Biodiversity in Nepal: status and conservation. S. Devi, Saharanpur and Tec press Books, Bangkok, Thailand.

COTTON, C M (1996) Ethnobotany, Principles and Application. Brisbane, Toronto, Singapore, John Wiley and Sons, New York.

CRONQUIST, A (1981) An integrated system of classification of flowering plants. Columbia University Press, New York, USA. 
DANGOL, D R; GURUNG, S B ( 1991) Ethnobotany of the Tharu tribe of Chitwan district, Nepal. Int. J. Pharmacognosy 29 (3): 203-209.

DANGOL, D R (2002) Ethnobotanical research and education in Chitwan district Nepal. J. Inst. Agric. Anim. Sci. 23: 1-7.

GHIMIRE, S K ( 2008) Sustainable harvesting and management of medicinal plants in the Nepal Himalaya: current issue, knowledge gaps and research priorities. In JHA, P K; KARMACHARYA, S B; CHHETRI, M K; THAPA, C B; SHRESTHA, B B (eds) Medicinal plants in Nepal: an Anthology of Contemporary Research. Ecological Society, Nepal; pp 25-44.

GHIMIRE, SK; SHRESTHA, A K; SHRESTHA, K K; JHA, P K (2000) Plant resource use and human impact around Royal Bardia National Park, Nepal. Journal of Natural History Museum 19: 3-26.

HMG NEPAL (1970) Medicinal plants of Nepal. Bull. Dep. of Med. Plants, no.-3, Department of medicinal plants, Kathmandu, Nepal.

HMG NEPAI (1984) Medicinal plants of Nepal: Bull. Dep. of Med. Plants, no.-10, Department of medicinal plants, Kathmandu, Nepal.

HMG NEPAL (2001) Flowering plants of Nepal. Ministry of forest and soil conservation, Department of Plant Resources, Kathmandu, Nepal.

HARSHBERGER, J W (1896) Purposes of ethnobotany. Bot. Gaz. 146: 154.

HOOKER, J D (1883) Classification of Plants. Genera Plantarum.

IGNACIMUTHU, S; AYYANAR, M; SIVARAMAN, S (2006) Ethnobotanical investigations among tribes in Madurai district of Tamilnadu, India. J. Ethnobiology and Ethnomedicine 2: 2-25. doi: 10.1186/1746-4269-2-25.

IUCN Nepal (2000) National register of medicinal plants. IUCN-The World Conservation Union, Nepal.

MANANDHAR, N P (1986) A contribution to the ethnobotany of Mooshar tribes of Dhanusha district, Nepal. Journal of Natural History Museum 10 (1-4): 53-64.

MANANDHAR, N P (2002) Plants and people of Nepal. Timber Press Portland, Oregan, USA.

RAI, M B (2003) Medicinal plants of Tehrathun district, eastern Nepal. Our Nature 1: 42-48.

RAJBHANDARI, KR (2001) Ethnobotany of Nepal. Ethnobotanical Society of Nepal (ESON), Kathmandu, Nepal.

SANKARANARAYANAN, S; BAMA P; RAMCHANDRAN, J; BAMA SATHYA, S (2010) Ethnobotanical study of medicinal plants used by traditional users in Villupuram district of Tamilnadu, India. Journal of Medicinal Plants Research 12: 1089-1101.

SHRESTHA, K K (1998) Dictionary of Nepalese plant name. Mandala Book Point, Kathmandu, Nepal.

SHRESTHA, P M; DHILLION, S S (2003) Medicinal plants diversity and use in the high lands of Dolkha district. Nepal. J. Ethnopharmocology 86(1): 81-96.

SINGH, AG; KUMAR, A; TIWARI, D D (2012) An ethnobotanical survey of medicinal plants used in Terai forest of western Nepal. J. Ethnobiology and Ethnomedicine 16: 8-19. doi: 10.1186/1746-4269-8-19.

SINGH S (2015) Ethnobotanical study of some wild herb species Parsa district forest of Nepal. Int. J. Pharmacognosy and phytochemistry 4(2): 32-40.

STAINTON, A (1988) Flower of the Himalaya, a supplement. Oxford University Press. New Delhi, India.

YADAV, R K P (1999) Medicinal plants and traditional practice in eastern part of Parsa district, Nepal, Proceeding of the $3^{\text {rd }}$ National Conference on Science and Technology. RONAST, Lalitpur, Nepal; pp1421-1426. 